\title{
Flexural behaviour of High-performance concrete beams under Cyclic loading conditions
}

\section{DOI:10.36909/jer.ACMM.16361}

\author{
N Ganapathy Ramasamy ${ }^{1}$, P R Kannan Rajkumar ${ }^{1^{*}}$ \\ ${ }^{1}$ Assistant Professor, ${ }^{2}$ Associate Professor, \\ SRM Institute of Science and Technology SRM Nagar, Kattankulathur 603 203, \\ Chengalpattu, INDIA \\ *E-mail: ganapatn@srmist.edu.in, tokannanonly@gmail.com: Corresponding author.
}

\begin{abstract}
Flexural behaviour of high-performance concrete (HPC) was affected by various parameters and plays a vital role in the strength of concrete. Present study aims in deciphering the role of cyclic loading on HPC reinforced with steel fibers. The study was carried out by casting of beams with hooked end steel fiber reinforced concrete with various grades (M60, M80, M100) and with admixtures (GGBS and Silica fume). Cast beams were studied for compressive strength, tensile strength, and flexural strength under cyclic loading. The study shows that there was a significant increase in compressive strength of HPC mixed with $1.0 \%$ of steel fiber. Flexural strength was found to be comparatively higher (upto $15 \%$ for all grades) for $1.25 \%$ steel fiber mixed HPC. Direct tensile strength is found to be higher than split tensile strength. Addition of steel fiber in HPC beam under cyclic loading, resulting in delayed or late development of cracks with decreased crack size.
\end{abstract}

Keywords: Mineral Admixtures, High performance concrete, Hooked-end Steel fiber, Cyclic loading, Direct Tensile test

\section{INTRODUCTION}

Demand for improved quality of concrete have paved way for various advancements in concrete technology including materials, mixture proportioning, recycling, structural design, durability requirements, testing, and specifications (Seabrook et al., 1984).Many studies have been carried out, in the past few decades, by various researchers, the properties like mechanical and durability improved when quality of the concrete is improved in service life and environmental aspects (Prajapati et al., 2017).In recent times research on High performance Concrete (HPC) have been carried out to address the improvement of specific property of concrete. High-Performance concrete (HPC) was used to meet the specific 
functional requirement of the concrete. To produce high-performance concrete, chemical and mineral admixtures are used along with an addition to basic ingredients that are used for normal concrete(Prajapati et al., 2017). Mineral Admixtures form an essential part of the High-Performance Concrete mix and are added to improve its mechanical and durability properties(Qureshi et al., 2020). In general, the packing characteristics of HPC are increased due to the addition of mineral admixtures.(Khan et al., 2014)On their review on mineral admixtures found the admixtures like Fly Ash, Silica Fume, Ground granulated Blast Furnace Slag, Metakaolin and Rice husk Ash affects the strength of concrete with their individual characteristics. Silica Fume (SF) and Ground Granulated Blast furnace slag (GGBS), due to their high pozzolanic character,have been used as admixtures in concrete(Halstead, 1986),(Abd Elrahman \& Hillemeier, 2014). GGBS with particle size less than $45 \mu \mathrm{m}$ and rough texture possess cementitious and pozzolanic character; on the other hand, silica fume with particle size less than $0.1 \mu \mathrm{m}$ shows active pozzolanic character (Abd Elrahman \& Hillemeier, 2014)The addition of silica fume and GGBS accelerates the concrete's secondary cementitious reaction, which leads to increases in strength. When calcium hydroxide reacted with silica, formation of tricalcium silicate takes place. The pozzolanic reaction may be represented as eq. (1) (Patel \& Shah, 2013):

$$
3 \mathrm{Ca}(\mathrm{OH})_{2}+\mathrm{SiO}_{2}=3 \mathrm{CaO} \cdot \mathrm{SiO}_{2}+3 \mathrm{H}_{2} \mathrm{O} .
$$

The volume change in concrete was happening in plain concrete and similar brittle material will lead to the micro-crack before it undergoes loading, it was because of the drying shrinkage. The crack developed in the concrete beam can be arrested by the addition of steel fibers distribution in the concrete like closely spaced and dispersed uniformly and it will also improves the static and dynamic properties. The addition of steel fiber in to the concrete improves the flexural strength, ductility, bridging effect in crack development. On the negative side, it reduces the workability(Wang et al., 2008), which is overcome by adding water reducers into concrete. The coalescence and unstable growth developed in the concrete may be getting delayed in the presence of fiber in the concrete, it act as a bridge between the materials and act as a the stress transfer media.The performance of steel fiber in concrete depends on many factors such as type of steel fiber, shape, length, cross-section, tensile strength, fiber content, bond strength, matrix strength, mixed concrete composition and mixing in concrete.

The flexural properties of concrete composites are so important in the mix design and application of concrete composites(Wang et al., 2008). However, few studies have reported 
the effect of fiber (steel, polypropylene, natural fibers, etc.) and admixtures (like GGBS, SF, FA, RHA) on flexural strength and modulus of elasticity of concrete composites. The impact of cement and concrete blend on flexural strength is controlled by the factors like size of the member, nature of admixture, curing conditions, and concrete strength (Zhang et al., 2012). The steel fiber reinforced beams undergo large displacements without developing wider cracks compared to control beams. Both load and moment carrying capacity of steel fiber reinforced concrete were significantly increased. Strength of the concrete is reduced when it is subjected to cyclic load. It is reported that (Paul \& Hussain, 2020)increasing reinforcement ratio decreases the interface damage resulting due to loading, decreases stiffness and also increases number of cyclic load that it can withstand. Beams in particularexhibits flexural failure when subjected to static loading,andwhen cyclic loading is applied, exhibit failure resulting due to damage of bonding between concrete and reinforcement. Influence of cyclic loadings that a structure can withstand/ support is controlled by the magnitude, cycles, and rate of loading that is applied on the structure(Elinwa\& Kabir, 2019).Present study aims to address flexural strength of HPC prepared by using admixtures and steel fiber. Mechanical properties were carried out on conventional concrete and HPC. The study also aims to understand the effect of cyclic loading on flexural strength using hysteresis loop.

\section{MATERIALS AND METHODS}

HPC mix design carried out in accordance with ACI 211.9 as well as described by aitcin(Neville \& Aïtcin, 1998). High performance concrete is produced by mixing ordinary Portland cement (OPC), M-sand as fine aggregate, the coarse aggregate of size $10-12.5 \mathrm{~mm}$, Silica fume \& GGBS as mineral admixtures, hooked end steel fiber, and to improve workability,superplasticizers are used. The properties of materials used for this study are presented in Table 1. 
Table 1 Properties of Materials used with standard values

\begin{tabular}{|c|c|c|c|c|c|}
\hline $\begin{array}{c}\text { S.N } \\
\text { o }\end{array}$ & Material & Properties & Result & $\begin{array}{l}\text { Standard } \\
\text { values }\end{array}$ & References \\
\hline \multirow{3}{*}{1} & \multirow{3}{*}{$\begin{array}{c}\text { Portland } \\
\text { cement (OPC) }\end{array}$} & Sp.Gravity & 3.12 & $\begin{array}{l}3.1 \text { to } \\
3.25\end{array}$ & \multirow[t]{3}{*}{ IS $12269-2013$} \\
\hline & & Initial setting time & $45 \mathrm{~min}$ & $>30 \mathrm{~min}$ & \\
\hline & & Final setting time & $450 \mathrm{~min}$ & $<600 \min$ & \\
\hline 2 & $\begin{array}{l}\text { M-Sand } \\
\text { (Zone- II) }\end{array}$ & Sp.Gravity & 2.73 & 2.5 to 2.9 & \multirow{2}{*}{ IS 383-2016 } \\
\hline 3 & C. $\mathrm{A}(<12.5 \mathrm{~mm})$ & Sp.Gravity & 2.87 & 2.5 to 3.0 & \\
\hline 4 & SF & Sp.Gravity & 2.2 & 2.2 to 2.3 & ACI 226-1988 \\
\hline 5 & GGBS & Sp.Gravity & 2.87 & $2.8-3.1$ & IS 16714: 2018 \\
\hline
\end{tabular}

The length of and diameter of hooked end steel fibers is $35 \mathrm{~mm}$ The diameter is 0.55 with an aspect ratio of is 64 is used. The Elastic modulus of the hooked end steel fiber is 200GPa. Silica fume and GGBS with size fractions of $<0.1 \mu \mathrm{m}$ and $45 \mu \mathrm{m}$ respectively, were procured from commercial vendors for the present study. High range water reducers (Auromix 300) used in this study are of polycarboxylic ether base, with specific gravity of 2.2 , poses capability of high dispersion of cement. The mixing of concrete is done with a pan mixer. The dry mix has been done for approximately 5 mins followed by addition of superplasticizer to the water; finally, fibers were added to the concrete with uniform dispersion of fibers. Steel fibers are added to the concrete on the basis of volume fraction as $0.25 \%, 0.5 \%$, $0.75 \%, 1 \%, 1.25 \%$, respectively. Servo computerized compression testing machine of $1000 \mathrm{kN}$ was used to test the compressive strength of the cast cubes. Tensile strength of highperformance concrete was performed by two methods: Direct tensile test and Split tensile test. Cyclic loading tests for HPC were carried out using Self Straining loading frame of 400 $\mathrm{kN}$ capacity.

\section{RESULT AND DISCUSSION}

\section{Compression test}

The compressive strength was estimated for the cube specimen of size $100 \mathrm{~mm}$ with different grades of concrete (M60, M80, M100) and fiber fractions (varying from $0.25 \%$ to $1.25 \%$ ) at 7, 14, and 28 days. Compressive strength of M60-M100 with steel fibers detailed in figure 13. High compressive strength was achieved for fiber fraction of $1 \%$ in all the concrete grade M60, M80, M100, and a similar trend was observed (Lee et al., 2015). 


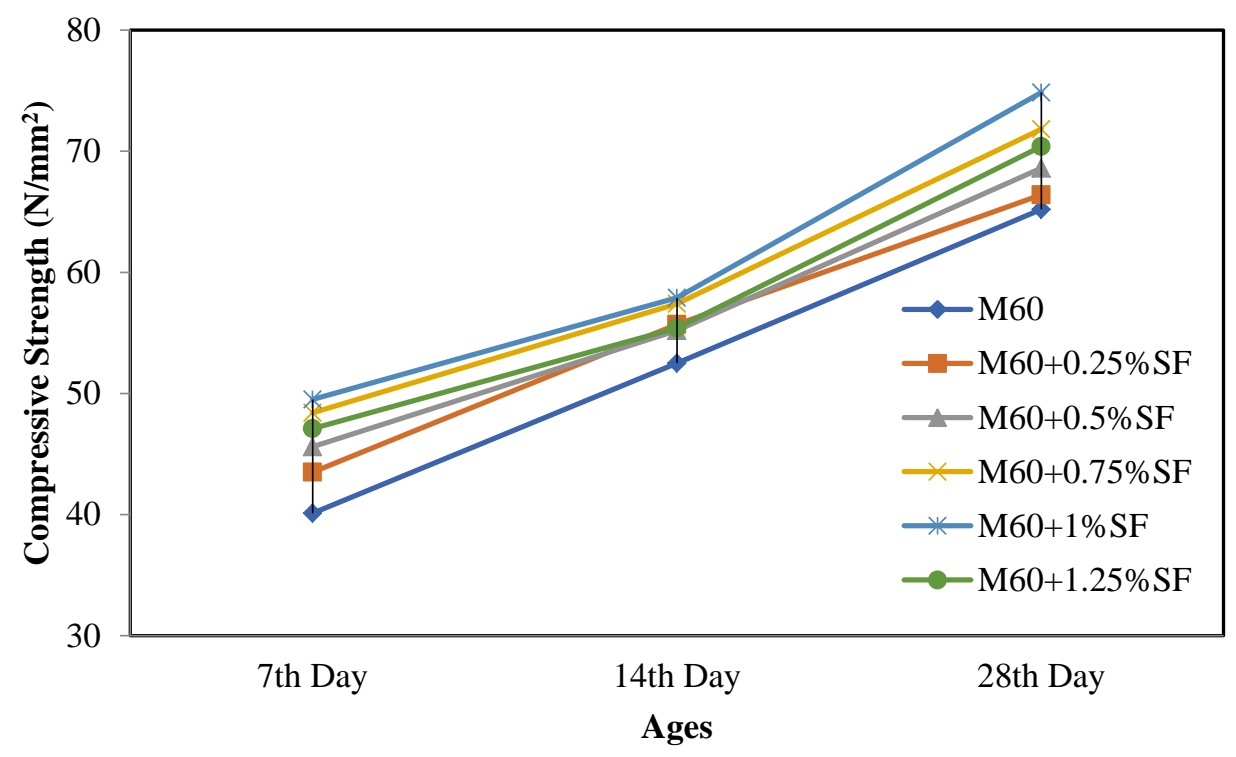

Figure 1 Compressive Strength of M60 with fiber Fractions

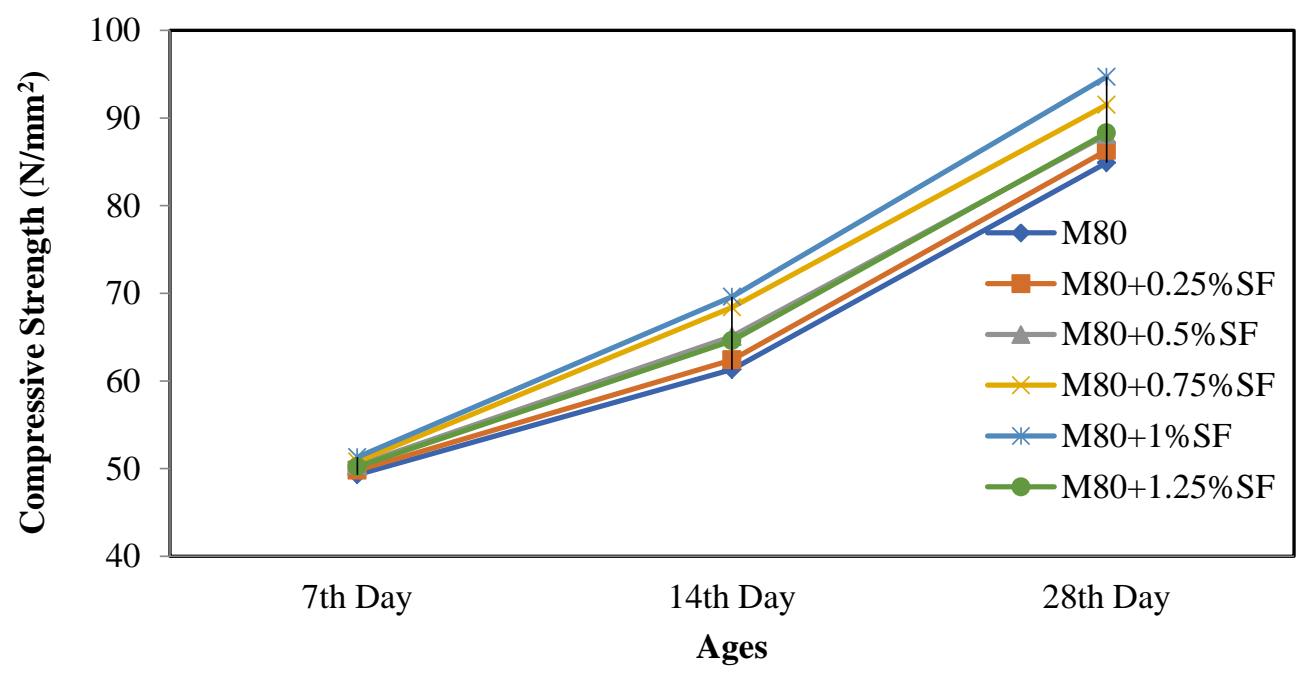

Figure 2 Compressive Strength of M80 with fiber Fractions

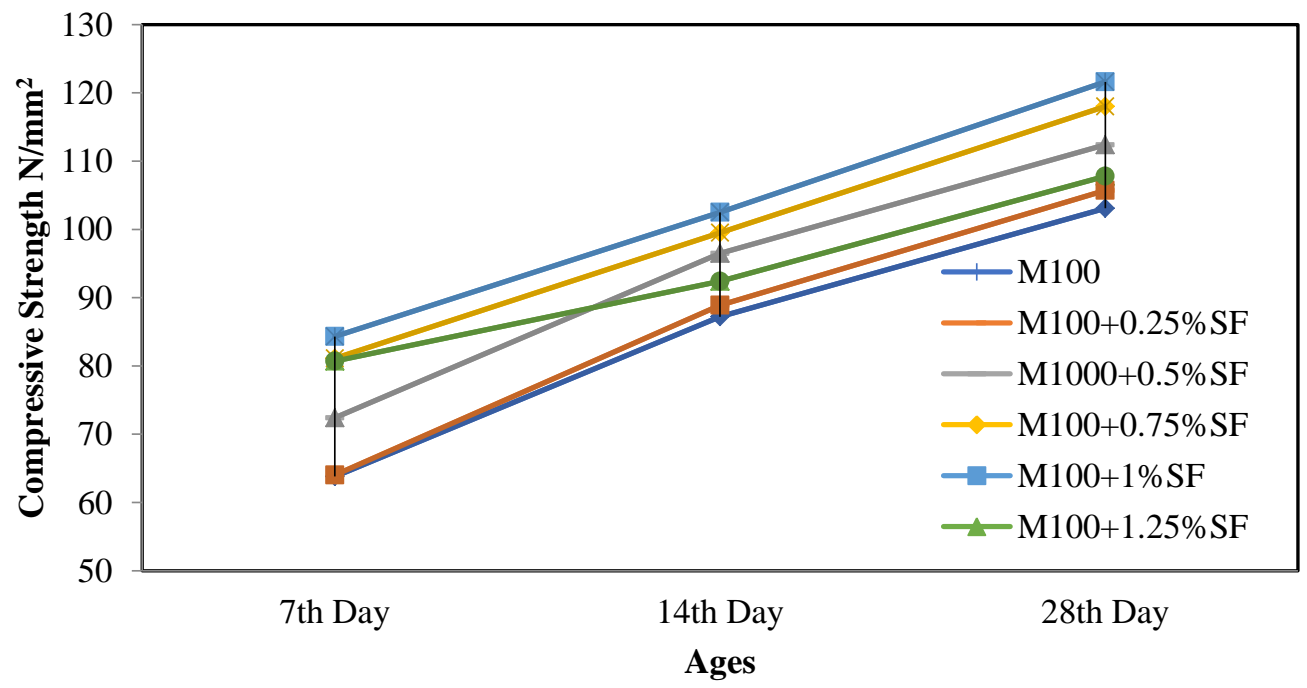


Figure 3 Compressive Strength of M100 with fiber Fractions

In M60 grade concrete, with the addition of 1\% of steel fiber in volume fraction, the target strength increases by $25 \%$.Likewise, for M80 and M100 the increment was $18 \%$ and $25 \%$ in target strength respectively. Compressive strength for fiber mix greater than $1 \%$ is observed to decrease due improper fiber dispersion that results in balling effect of concrete.

\section{Tensile strength and Flexural strength of HPC}

Tensile and flexural strength with different fiber fractions in different grades of concrete was studied and presented in table2. Direct tensile test of concrete was performed in concrete prism (dog bone shaped) specimen with a thickness of $75 \mathrm{~mm}$ to investigate the direct tensile strength of concrete is shown in figure 5. The two ends of the concrete specimens (dog bone shaped) are anchored in the universal testing machine of $1000 \mathrm{kN}$ capacity and tensile load was applied on the specimen (Fig. 5). The split tensile test was carried out in cylindrical concrete specimens that were placed in a horizontal direction, and load was applied over the concrete specimens. In the comparison (table 2), the direct tensile strength is lower than the split tensile strength of concrete, especially in HPC.The direct tensile strength results were more significant than split tensile strength test with variation of about $20 \%$ higher for direct tensile strength. The tensile strength increased by more than $100 \%$ for all the grades of concrete with the addition of $1.25 \%$ fiber fraction; a similar trend was observed (Ramkumar et al., 2020). The observed increase in direct tensile strength is due to the high yield property of fiber reinforced concrete as the effect is absent in split tensile strength where compressive action is predominant.

Table 2 : Tensile \& flexural Strength of M60, M80, M100 with fiber fractions

\begin{tabular}{|c|c|c|c|c|}
\hline Mix & $\begin{array}{c}\text { Percentage } \\
\text { replacemen } \\
\mathbf{t}\end{array}$ & $\begin{array}{c}\text { Direct Tensile } \\
\text { Strength } \\
\left(\mathbf{N} / \mathbf{m m}^{\mathbf{2}}\right)\end{array}$ & $\begin{array}{c}\text { Split Tensile } \\
\text { Strength } \\
\left(\mathbf{N} / \mathbf{m m}^{\mathbf{2}}\right)\end{array}$ & $\begin{array}{c}\text { Flexural } \\
\text { Strength } \\
\left(\mathbf{N} / \mathbf{m m}^{\mathbf{2}}\right)\end{array}$ \\
\hline $\mathrm{M} 60$ & $0 \%$ & 3.92 & 3.25 & 6.80 \\
\hline $\mathrm{M} 60+0.25 \% \mathrm{SF}$ & $0.25 \%$ & 4.15 & 4.01 & 7.20 \\
\hline $\mathrm{M} 60+0.5 \% \mathrm{SF}$ & $0.50 \%$ & 5.75 & 5.24 & 7.64 \\
\hline $\mathrm{M} 60+0.75 \% \mathrm{SF}$ & $0.75 \%$ & 6.25 & 5.37 & 8.21 \\
\hline $\mathrm{M} 60+1 \% \mathrm{SF}$ & $1.00 \%$ & 7.25 & 5.45 & 8.84 \\
\hline $\mathrm{M} 60+1.25 \% \mathrm{SF}$ & $1.25 \%$ & 8.12 & 6.43 & 9.13 \\
\hline $\mathrm{M} 80$ & $0 \%$ & 4.92 & 4.56 & 7.54 \\
\hline $\mathrm{M} 80+0.25 \% \mathrm{SF}$ & $0.25 \%$ & 5.99 & 5.27 & 8.12 \\
\hline $\mathrm{M} 80+0.5 \% \mathrm{SF}$ & $0.50 \%$ & 7.54 & 6.57 & 8.78 \\
\hline $\mathrm{M} 80+0.75 \% \mathrm{SF}$ & $0.75 \%$ & 8.64 & 7.21 & 9.18 \\
\hline
\end{tabular}




\begin{tabular}{|c|c|c|c|c|} 
M80+1\%SF & $1.00 \%$ & 9.21 & 7.54 & 9.56 \\
\hline M80+1.25\%SF & $1.25 \%$ & 9.59 & 7.64 & 10.14 \\
\hline M100 & $0 \%$ & 6.02 & 6.95 & 8.34 \\
\hline M100+0.25\%SF & $0.25 \%$ & 7.54 & 7.33 & 8.83 \\
\hline M100+0.5\%SF & $0.50 \%$ & 8.01 & 7.8 & 9.18 \\
\hline M100+0.75\%SF & $0.75 \%$ & 8.54 & 8.14 & 9.76 \\
\hline M100+1\%SF & $1.00 \%$ & 9.64 & 8.42 & 10.59 \\
\hline M100+1.25\%SF & $1.25 \%$ & 10.72 & 8.59 & 11.16 \\
\hline
\end{tabular}

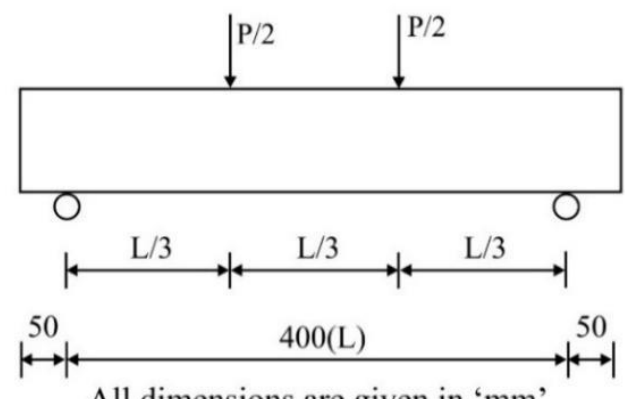

All dimensions are given in ' $\mathrm{mm}$ '

Figure 4 Flexural Specimen

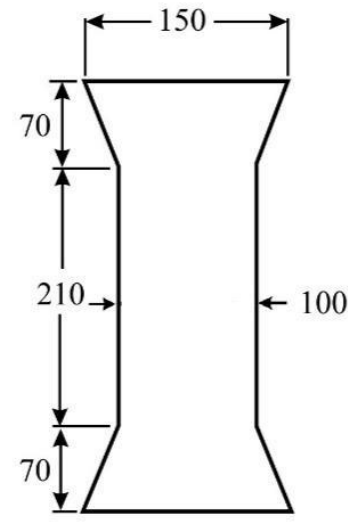

All dimensions are given in ' $\mathrm{mm}$ '

Figure 5 Direct tensile test Specimen

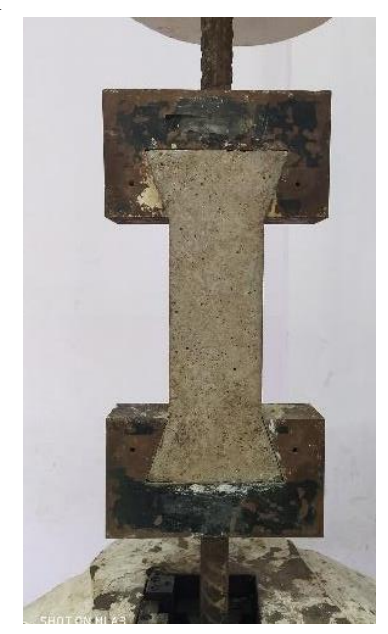

Figure 6 Direct tensile Experimental Setup The flexural strength of HPC fiber concrete specimens was tested in the flexure specimen of size $100 \times 100 \times 500 \mathrm{~mm}$. The test was carried out under a four-point loading test, and all the flexural strength results were detailed in table 2. Flexural specimen shown in figure 4 . The studied HPC's flexural strength shows an increase in strength at $1.25 \%$ (in volume) of fiber mixed in concrete compared to that of other fractions. Increase in flexural strength, which was maintained/ carried out only upto $1.25 \%$ as it was considered as optimal fiber content, was due to high yielding of concrete due to presence of steel fiber content. a $30 \%$ increase in flexural strength was observed for $1.25 \%$ fiber fraction in all the concrete grades of M60, M80 and M100, a similar trend was observed(Halstead, 1986). 


\section{Cyclic loading of HPC}

The half cyclic loading was applied in HPC specimen and increase in theloading rate was $2 \mathrm{kN}$.Cyclic loading in HPC was increased in step wise basis with an increment of $2 \mathrm{kN}$ and carried out for different cycles of $10 \mathrm{kN}, 20 \mathrm{kN}$ and so on till the maximum ultimate loading is reached. Upon reaching maximum load $(10 \mathrm{kN}, 20 \mathrm{kN} \ldots)$ the load was decreased at $2 \mathrm{kN}$ interval till it reached zero. Residual strain/ deflection was considered for further cycles of the experimental process. The test setup and dimension details of the specimens are given in fig (7-16). Beams were strengthened with two $12 \mathrm{~mm}$ reinforcement bars at bottom and two $10 \mathrm{~mm}$ reinforcement bars at top, $8 \mathrm{~mm}$ stirrups at $150 \mathrm{~mm}$ center to center spacing was provided. Those results were studied to understand the behavior of different grades of concrete.The hysteresis loop was drawn using deflection vs. load plot. It is observed that the first crack occurred in the normal beam nearly in the 2nd cycle and in the case of highperformance concrete beam, it occurred in the $3^{\text {rd }}$ cycle. The deflection value was low in High performance concrete with fiber compared to normal high-performance concrete. Hysterisis loop (fig.14,16) shows that performance of HPC with fiber content showed significant improvement when compared with conventional HPC.

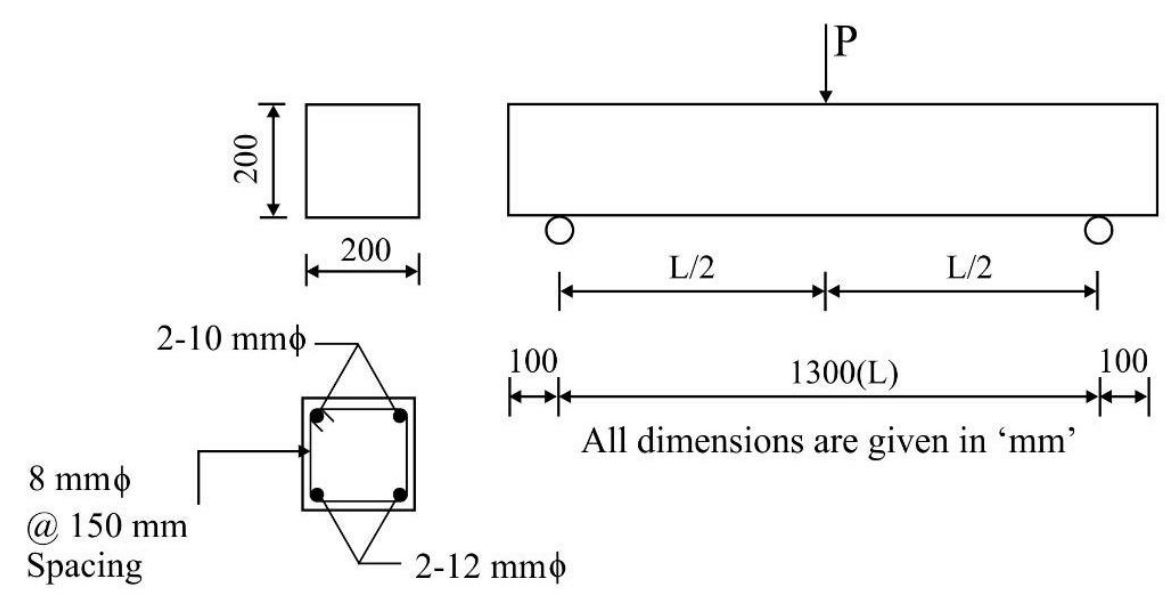

Figure 7 Details of cyclic loading on beams 


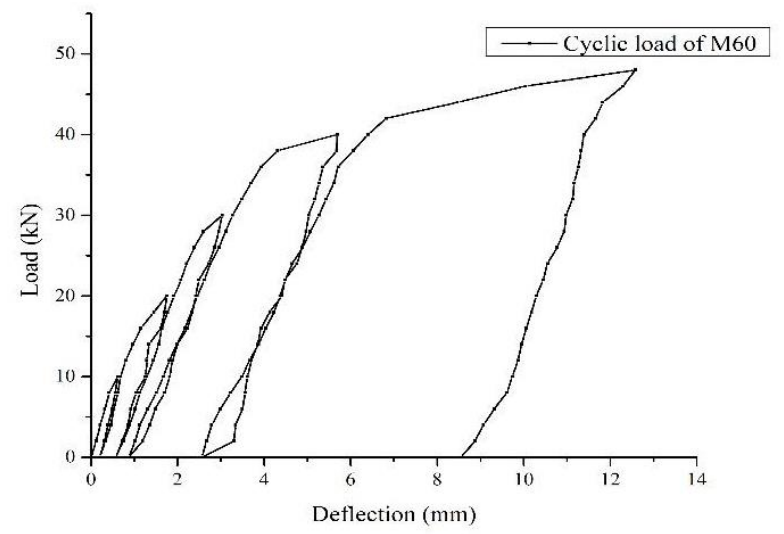

Figure 8 Cyclic Load curve for M60 grade of concrete

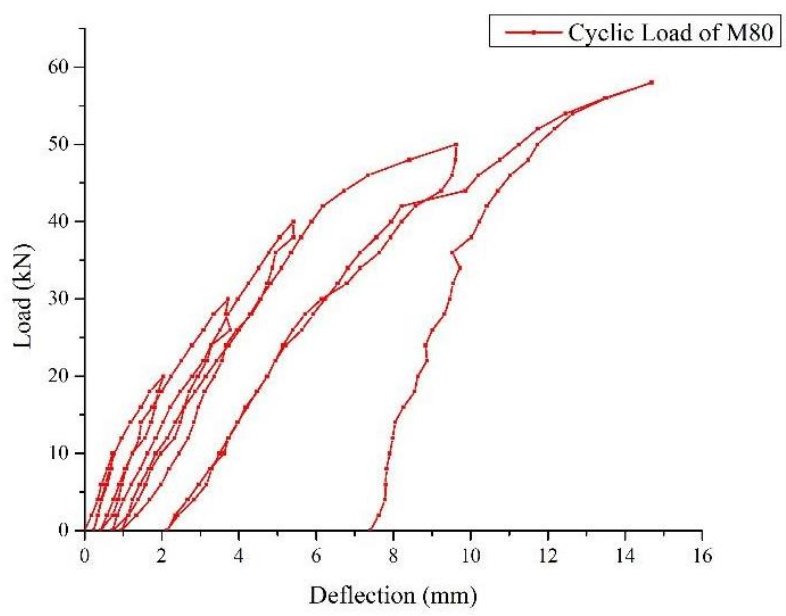

Figure 10 Cyclic Load curve for M80 grade of concrete

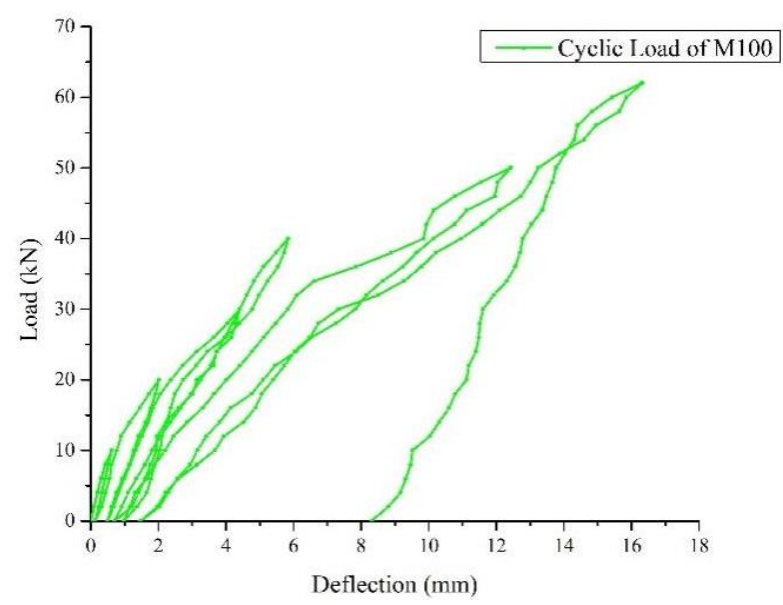

Figure 12 Cyclic Load curve for M100 grade of concrete

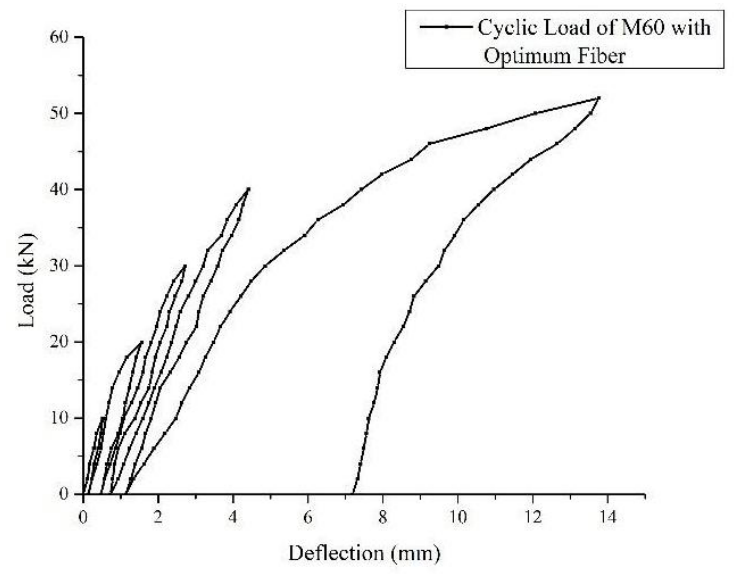

Figure 9 Cyclic Load curve for M60 grade of concrete with fiber

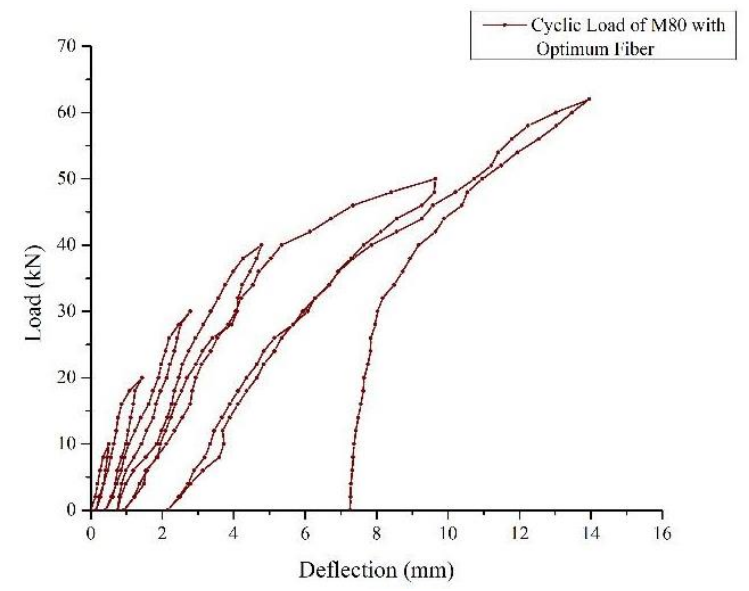

Figure 11 Cyclic Load curve for M80 grade of concrete with fiber

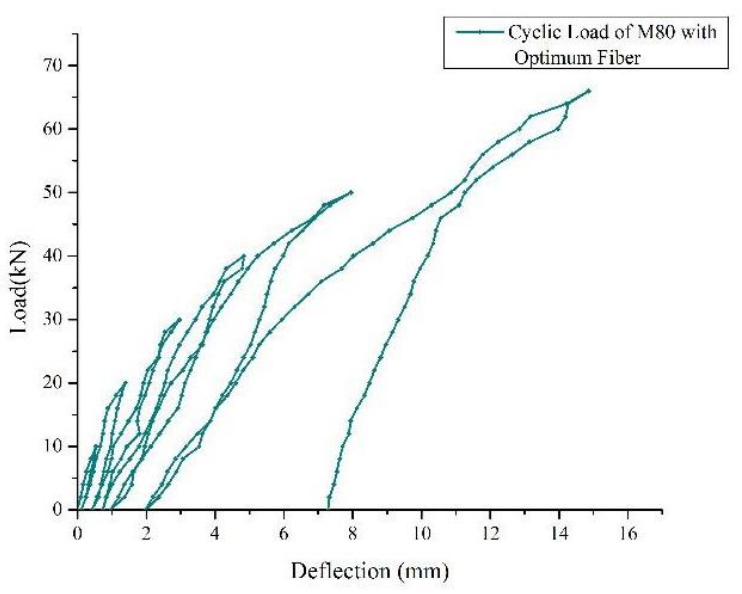

Figure 13 Cyclic Load curve for M80 grade of concrete with fiber 


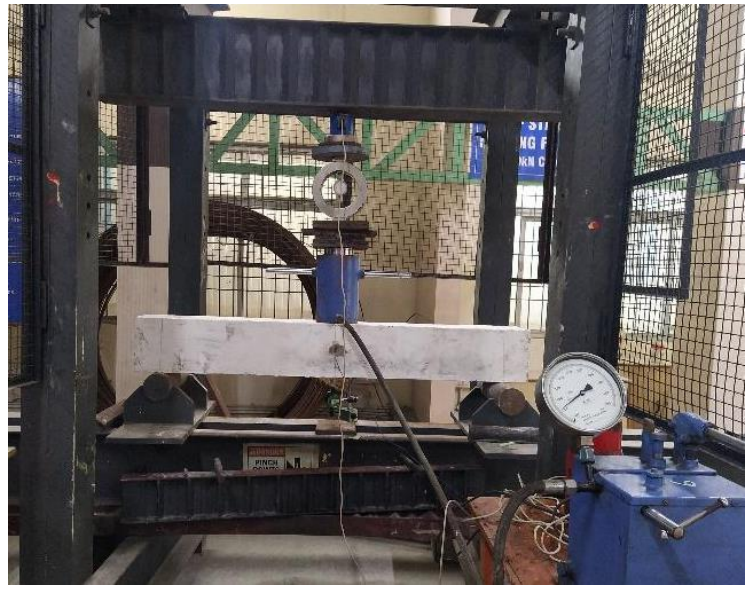

Figure 14 Experimental setup of Cyclic Load

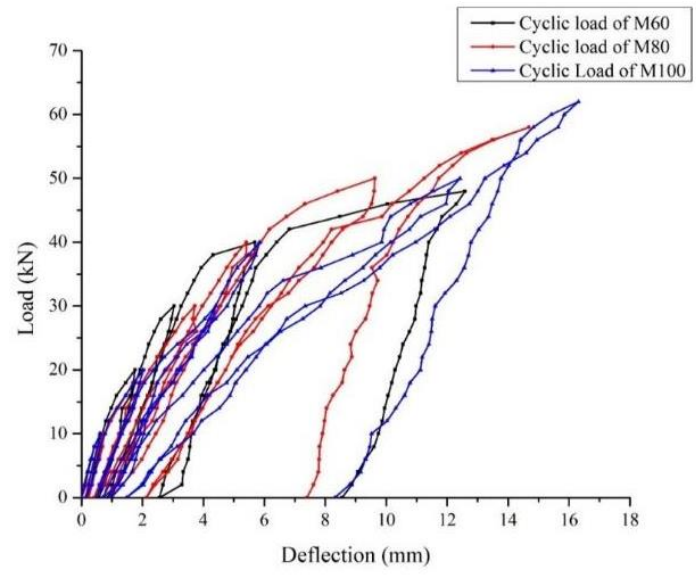

Figure 15 Cyclic Load curve for M60, M80,M100 grade of concrete

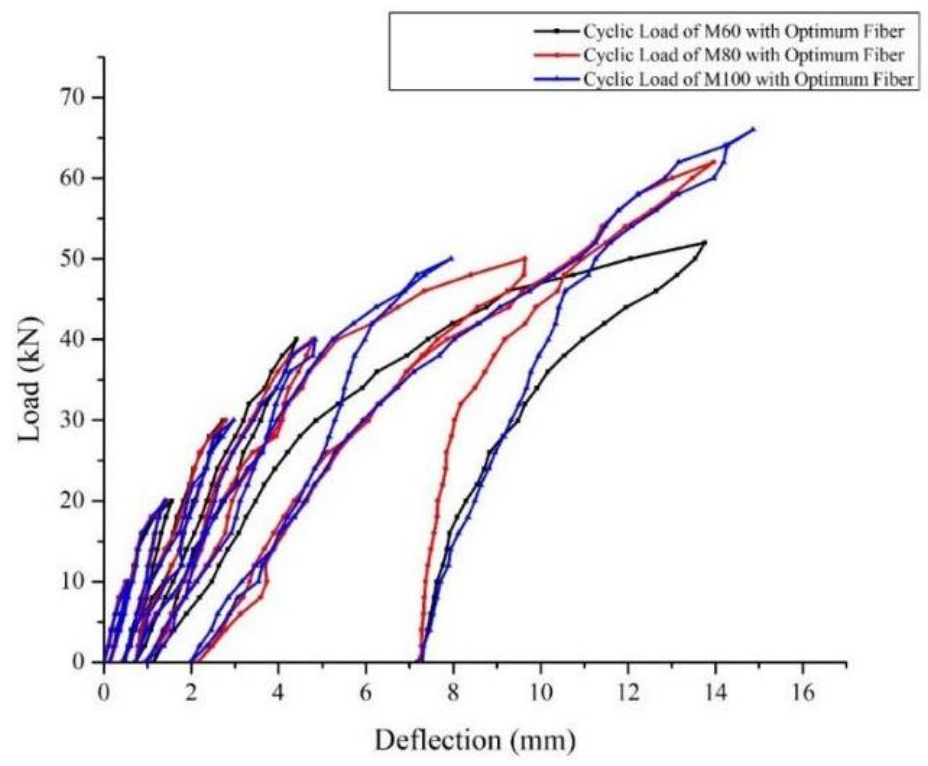

Figure 16 Cyclic Load curve for M60, M80, M100 grade of concrete with optimum Fiber

The hysteresis loop was wider for low grade conventional HPC whereas fiber mixed HPC showed a narrower loop indicating lower deflection; a similar trend was observed (Ganesan et al., 2014). The fiber mixed HPC beams showed greater dimensional stability which is evident from decrease in crack width and length.

\section{CONCLUSION}

Compressive strength of high performance concrete (HPC) was higher, with a minimum of $15 \%$ increase in strength, at $1 \%$ fiber mix concrete of all grades. On the ther hand flexural and tensile strength showed maximum strength at $1.25 \%$ fiber mix concrete. Percentage of increase in tensile and flexural strength at $1.25 \%$ fiber mix concrete is $30 \%$ and $>100 \%$ respectively. Balling effect and improper dispersion of fibers plays a major role in decrease in strength of concrete mixed with higher firber fractions. High percentage (upto 20\%) of high direct tensile strength compared to that of split tensile strength was observed due to high 
yielding of capacity of fibers. High performance concrete shows higher load carrying capacity under cyclic load condition under lesser strain rate. From the study it can be concluded that, at larger displacements, addition of steel fibers in HPC have resulted in high cyclic loading capacity without developing any large and wider cracks when compared with control beams.

\section{REFERENCES}

Seabrook P.T. ,1984. "State-of-the-Art Report on Fiber Reinforced Shotcrete.," Concr. Int., vol. 6 , no. 12 , pp. $15-27$.

Prajapati.A, Prajapati.P , and Qureshi. M, 2017 “ An experimental study on highperformance concrete using mineral admixtures," vol. 5, no. 2, pp. 2080-2086.

Qureshi. L. A, Ali. B, and Ali. A, 2020. "Combined effects of supplementary cementitious materials (silica fume, GGBS, fly ash and rice husk ash) and steel fiber on the hardened properties of recycled aggregate concrete," Constr. Build. Mater., vol. 263, p. 120636.

Khan. S. U, Nuruddin. M. F, Ayub. T, and Shafiq. N,2014. "Effects of different mineral admixtures on the properties of fresh concrete," Sci. World J., vol. 2014.

Halstead. W. J,1986. "Use of Fly Ash in Concrete.," Natl. Coop. Highw. Res. Program, Synth. Highw. Pract., vol. 96, no. Reapproved, pp. 1-34,

Abd Elrahman. M and Hillemeier. B, 2014. "Combined effect of fine fly ash and packing density on the properties of high performance concrete: An experimental approach," Constr. Build. Mater., vol. 58, pp. 225-233.

Patel. V and Shah. N, 2013.“A Survey of High Performance Concrete Developments in Civil Engineering Field," Open J. Civ. Eng., vol. 03, no. 02, pp. 69-79.

Wang.A , Niu. J, and Zhang. C, 2008. "The mechanism of the effect of mineral admixtures on the expansion of alkali-silica reaction," J. Wuhan Univ. Technol. Mater. Sci. Ed., vol. 23, no. 3, pp. 376-380.

ACI Committee 211, “211.9R-18: Guide to Selecting Proportions for Pumpable Concrete," p. 51, 2018.

Zhang. P, Li. Q, and Sun. Z, 2012. "Effect of polypropylene fibre on flexural properties of concrete composites containing fly ash and silica fume," Proc. Inst. Mech. Eng. Part L J. Mater. Des. Appl., vol. 226, no. 2, pp. 177-181.

Paul. A and Hussain. $M$,2020. "Sustainable Use of GGBS and RHA as a Partial Replacement of Cement in the Stabilization of Indian Peat," Int. J. Geosynth. Gr. Eng., vol. 6 , no. 1 . 
Elinwa. A and Kabir. N ,2019. "Flexural Strength and Compressive Strength Relations of Hospital Waste Ash-Concrete," SSRN Electron. J., no. January

Vaz. A. P. R, Shehata. I. A. E, Shehata. L. C. D, and Gomes R. B, 2017. "Behaviour under cyclic loading of strengthened beams," Rev. IBRACON Estruturas e Mater., vol. 10, no. 6, pp. 1245-1272.

Aslani. F and Jowkarmeimandi. R, 2012. "Stress-strain model for concrete under cyclic loading," Mag. Concr. Res., vol. 64, no. 8, pp. 673-685.

Neville. A and Aïtcin. P. C, 1998. "High performance concrete - An overview," Mater. Struct. Constr., vol. 31, no. 2, pp. 111-117.

Bureau of Indian Standards (BIS),2019. “Concrete Mix Proportioning- Guidelines,” Bur. Indian Stand, vol. Second Rev, no. January, pp. 1-40.

Ganapathy Ramasamy. N, Lakshmipathy. M., and Kannan Rajkumar. P. R , 2020. “Optimization and Experimental investigation of High-Performance concrete," IOP Conf. Ser. Mater. Sci. Eng., vol. 912, no. 6.

Lee. S. C, Oh. J. H, and Cho. J. Y, 2015."Compressive behavior of fiber-reinforced concrete with end-hooked steel fibers," Materials (Basel)., vol. 8, no. 4, pp. 1442-1458.

Ramkumar. K. B, Kannan Rajkumar. P. R, Noor Ahmmad. S, and Jegan. M, 2015. “A Review on Performance of Self-Compacting Concrete - Use of Mineral Admixtures and Steel Fibres with Artificial Neural Network Application," Constr. Build. Mater., vol. 261.

Ganesan. N, Indira. P. V, and Sabeena. M. V, 2014. "Behaviour of hybrid fibre reinforced concrete beam-column joints under reverse cyclic loads,"Mater. Des.,vol.54, pp. 686693. 